\title{
Yemen War: An Overview of the Armed Conflict and Role of Belligerents
}

\author{
Abdullah Al Dosari ${ }^{1} \&$ Mary George ${ }^{1}$ \\ ${ }^{1}$ Faculty of Law, University of Malaya, Malaysia \\ Correspondence: Abdullah Al Dosari, Faculty of Law, University of Malaya, Malaysia. E-mail: \\ aldosari@siswa.um.edu.my
}

Received: October 28, 2019

Accepted: November 24, 2019 Online Published: January 29, 2020

doi:10.5539/jpl.v13n1p53

URL: https://doi.org/10.5539/jpl.v13n1p53

\begin{abstract}
Since 2004, Yemen is facing a rebellious movement by a Shiite militant group called the Houthis ${ }^{1}$. The Houthis established a parallel rule in northern part of the country and occupied the capital Sana'a. Due to involvement of regional powers including Iran, UAE and Saudi Arabi the nature of conflict became both sectarian and separatist. Following the Arab uprising in 2011, the roots of recent conflict lies in the failure of political transition between the former President Ali Abdullah Saleh and his opposition. The geopolitical situation and support of Iran for the Houthis made the station in Yemen more complex. Therefore, the Gulf countries particularly Saudi Arabia was concerned because of the strategic and political situation of its fragile neighbor. This paper provides an insight to the conflict in various aspects including the role of conflicting parties, role of proxies, role of world powers and regional actors to analyze the conflict in a detailed manner. At the end study also discusses the most recent political and strategic developments having implication on the region.
\end{abstract}

Keywords: LOAC, IHL, armed conflict

\section{Historical Background of the Saudi-Yemen Relations}

\subsection{Saudi Arabia-Yemen Relations}

In 1934, resulting the Treaty of Taif ${ }^{2}$, the Saudi-Yemen relations were established first time after a brief Saudi-Yemen border war. Beside the border dispute, Yemen's support of an Asiri prince against Ibn Saud was another cause of war. In that brief conflict, Saudis were generally considered victorious. Following the war, the treaty calls for the withdrawal of forces and ends the war. Apart from normalization of relations and respecting sovereignty, it also provided a boundary mechanism to demark the border between the conflicting parties which is the most significant part of this treaty. However, the treaty of Taif was not very comprehensive. Hence, in 2000 , both the countries have concluded another international boundary treaty which is known as Treaty of $\mathrm{Jeddah}^{3}$ that cover many new areas which were not concluded in the Treaty of Taif ${ }^{4}$.

To understand the roots of recent interventions from different regional states and actors. It is pertinent to discuss the early history of Yemeni civil wars. In 1962, after a revolt and the removal of the Zaydi Imam, Ahmed bin Yahya of the Mutawakkilite, a war broke out between Republican and Royalist in Yemen, which led to intervention by many states. One hand, Egypt supported the Republican forces. While Saudi Arabia, with the support of Jordan and Britain, supported the Mutawakkilite Royalists. Saudi Arabia supported the Royalists with military and financial aid but, unlike Egypt, did not send any force. However, in 1967, resulting the defeat by Israel, Egypt withdrew its troops, but eventually the Republicans went on to win the civil war. Consequently, in 1970 Saudi Arabia recognized the Yemen Arab Republic.

In 1967, after the departure of British army from northern Yemen, a Marxist state named the People's Democratic Republic of Yemen came into being in the Southern part. Consequently, during the war between north and

\footnotetext{
${ }^{1}$ Shiite minority of Yemen's Zaidi community consist of 35 percent of Yemen's total population. Mostly habitant of northern part of Yemen. Generally, Zaidi community considered as Shiite, but they are distinct from Shia majority. The Houthi movement were found in late 1990s by the Houthi family to secure the interests of the Zaidi community as a religious group named Ansar Allah.

${ }^{2}$ Treaty of Islamic friendship and Arab brotherhood (Treaty of Taif), retrieved at https://peacemaker.un.org/saudiarabiayemen-taiftreaty34

3 The international boundary treaty (Treaty of Jeddah) 2000

4 Ibid
} 
southern Yemen, Saudi Arabia supported the north Yemen due to its ant-communist stance during that period. During that era, both the countries expressed their willingness for unification. Resulting the unification talks between the two parts in 1990 Unification was declared. For the unified Yemen, Ali Abdullah Saleh became the president for newly state. Saudi Arabia's relations with Yemen have changed drastically due to Ali Abdullah's stance in regional conflicts. During the Saddam Hussein's rein, resulting the strong ties with Saddam, Yemen's relation with Gulf and Saudi Arabia became worse. At this point of time Yemen also became the member of UN and formed Arab Cooperation Council in 1989. Resulting the Yemeni support for Saddam, Saudi Arabia expelled thousands of Yemenis working in Saudi Arabia which led the Yemeni economy into serious crises ${ }^{5}$. During that era, The Saudi relations with Yemen were greatly intensified because of Saudi's support for southern forces against Abdullah's regime. However, Abdullah Saleh prevailed and successfully succeeded his rule. Later, in 2004, Saudi Arabia again supported the Abdullah Saleh against the Houthis rebellion. Abdullah Saleh launched six brief wars against them and also against Al-Qaeda with the help of Saudi Arabia.

The historical background of the Saudi-Yemen relations suggests that the Saudi policy towards Yemen is driven by two factors i.e. containment and maintenance ${ }^{6}$. Therefore, Saudi Arabia ensure that Yemen Govt can not to be used against its own rule or to challenge the Saudi security while financial aid prevents the Yemeni Govt. from collapse which is also needed for the stability of the region.

In recent context, to enhance regional influence and control, the conflict between Saudi Arabia and Iran is again inviting multiple disputes in the region, where both the countries are supporting different combating sides including Yemen. This chapter analysis the role of both the countries including other factors while arguing that key drivers of conflict in Yemen are internal. However, the perceived roles of external drivers continue to affect the situation of the local players and of different regional powers.

\subsection{Rise of Houthis}

Shiite minority of Yemen's Zaidi community consist of 35 percent of Yemen's total population. Mostly habitant of northern part of Yemen. Generally, Zaidi community considered as Shiite, but they are distinct from Shia majority. The Houthi movement were found in late 1990s by the Houthi family to secure the interests of the Zaidi community as a religious group named Ansar Allah.

The Houthi's anti-US sentiments, the group came into conflict with the Saleh government. Due to its alliance with Sadia and the US the Saleh government was keen to restrain the extremists influence in the region including the Al-Qaeda and the Houthis with the US support. In 2004, resulting the political rift the hostilities with the Saleh government broke out. In the same year, the Houthi leader Hussein al-Houthi who was the original leader of Ansar Allah was killed by the Yemeni forces. After his death, Hussein's position was replaced by his brother Abd al-Malik al-Houthi as the supreme leader.

Fearing the US-Saleh alliance which was a mostly pro Sunni segment of Yemen, the Houthis demanded for equal rights for Zaidi community complaining discrimination against the community. Consequently, the protest movement erupt in 2011, provided the opportunity for the Houthis to launch and anti-government movement against Saleh's rule. Eventually the Houthis established a firm control of the Sa'ada governorate and significantly enhanced their power. Therefore, during 2012-2014 clashes between Ansar Allah (the Houthis) and Saleh forces with alliance on other Sunni groups continued in south Sa'ada region.

Initially, the Houthis, established as a reformist movement of Shia Islam that is largely unique to northern Yemen, have evolved themselves over the past decade into an armed group. In 2015, the Houthis takeover has plunged the state into chaos. While, due to heavy support from Iran, Saudi Arabia perceives the group as a proxy of Iran. To counter the Houthis influence and supporting the weaken Yemeni Govt., Saudi Arabia and its other allies are backing Yemen financially and strategically to prevent its security and economic collapse which is not a good sign for its neighboring countries and region.

Contrary to the common perception about conflicting parties in the Yemen that there are only two distinct groups i.e. Houthi, fighting against the army loyal to the president Abdrabbo Mansour Hadi who is also receiving support from the Saudi-led alliance. There are smaller groups present in different parts of Yemen who are not

\footnotetext{
${ }^{5}$ For more on the two countries' relations, see Brian Whitaker, 'Yemen and Saudi Arabia: a historical review of relations', Al-Bab, 25 March 2015

${ }^{6}$ Peter Salisbury, Yemen and the Saudi-Iranian ‘Cold War', Chatham House, February 2015
} 
precisely under the control of any of these conflicting parties ${ }^{7}$. Even Saudi-led alliance also carries different agendas as per different State's interests. With this, the potential presence of al-Qaeda and IS also makes situation in Yemen more complex.

In a Sunni dominant country, the success of relatively minor group is quite unique to many observers. Keeping in view that the Yemeni security forces have been divided and weak. With this, the former president was also been involved against the rule of Mansour Hadi. Saleh also organized demonstration against the Hadi to undermine his political position. Saleh's support was the most significant element of the Houthis success. Because of this, the loyalist of the former president Saleh in the Armed forces also joined the Houthis against the Yemeni government $^{8}$. Due to this, the Houthis have collected heavy weapon from these defectors ${ }^{9}$. Besides the military and political aid, Saleh factor was also brought some of the Sunni tribes in support of the Houthis who were previously in war with the Houthis. While politically, the Houthis movement bolstered by the popular unrest against the government. The Houthis have also motivated their Zaidi community in demonstrations and became the front-line opposition in political protests which brought them into a strong position in future advances. The ordinary people including a part of young radicals have also joined the Houthi movement following the fuel prices issue. Hence, all these factors joined together with the support of Iran made the Houthis the strongest opponent challenging Hadi's rule in Yemen.

\subsection{Prelude to the Conflict}

The Arab spring toppled several dictatorships in the middle east and the Yemen was not immune to the so called revolution. Since 1978, the former president Ali Abdullah Saleh was in power ${ }^{10}$. Despite of having two distinct parts of the Yemen's society which had been divided in two country there is no such history of sectarian violence. However, the Houthi group which belongs to the Shia sect had been considered as a threat against the Sunni rule in Sana'a. Allegedly, the Houthis have launched many attacks against the Yemeni forces with the help of Iran.

In 2011, as a rift against the ex-president Abdullah Saleh who was in power for more than thirty years was emerged. The protestors were motivated by the Yemeni opposition parties calling for the resignation of Abdullah $\mathrm{Saleh}^{11}$. Saleh tried to negotiate with the protestors by giving financial concessions and promises. However, several casualties were happened during these protests by the security forces. The heated situation became worse when in another protest a big number of people were killed by the Saleh loyalists. The killing of 45 anti-government protestors changed the whole scenario and can be termed as the shifting point of a political movement into an armed conflict. Following the mass killing, a very influential army commander with number of other army and air force officers changed their loyalty to the opposition ${ }^{12}$. However, the split in army did not potentially affect the core command and military security forces including the most powerful presidential guards remained loyal to the president ${ }^{13}$. Resulting the Arab upspring, the position of Abdullah Saleh became more fragile. UN backed efforts lead by Saudi Arabia, a transition deal was presented for the transferring of power. Therefore, in exchange of immunity form trial, Abdullah Saleh agreed on an agreement forwarded by the Gulf Cooperation Council to hand over the rule to his deputy Abdrabbo Mansour Hadi in November $2011^{14}$. Consequently, in early 2012, Abdrabbo Mansour Hadi being the only candidate was elected as the new president of Yemen ${ }^{15}$. Keeping in view that the Houthis including some other political groups have announced that they

\footnotetext{
7 P. Salisbury, Yemen: Stemming the Rise of a Chaos State, Chatham House, 25 May 2016, p 4, https://www.chathamhouse.org/sites/files/chathamhouse/publications/research/2016-05-25-yemen-stemming-rise-of-chaos-state-salisbury.pd f.

${ }^{8}$ Letter dated 20 February 2015 from the Panel of Experts on Yemen established pursuant to Security Council resolution 2140 (2014) addressed to the President of the Security Council https://www.securitycouncilreport.org/wp-content/uploads/s_2015_125.pdf

${ }^{9}$ Florence Gaub, 'Whatever happened to Yemen's army?', European Union Institute for Security Studies issue brief, April 2015

${ }^{10}$ Saleh ruled the country for more than three decades. See, note 2 .

11 Burrowes and M. Wenner, 'Mounting Challenge to the Saleh Regime', Encyclopedia Britannica, 6 April 2017, https://www.britannica.com/place/Yemen/Mounting-challenge-tothe-Salih-regime.

12 Top Army Commanders Defect in Yemen', Al Jazeera, 21 March 2011, http://www.aljazeera.com/news/middleeast/2011/03/2011320180579476.html.

13 International Crisis Group, Yemen's Military-Security Reform: Seeds of New Conflict?, 4 April 2013, p 12, https://www.crisisgroup.org/middle-east-north-africa/gulf-and-arabian-peninsula/yemen/yemen-s-military-security-reform-seeds-new-conflic t.

14 B. Whitaker, 'Yemen's Ali Abdullah Saleh Resigns - But It Changes Little', The Guardian, 24 November 2011, https://www.theguardian.com/commentisfree/2011/nov/24/yemen-ali-abdullah-saleh-resigns. The agreement was brokered by the former UN Secretary-General's Special Envoy to Yemen, Jamal Benomar.

15 M. Jamjoom, 'Yemen Holds Presidential Election with One Candidate', CNN, 22 February 2012, http://edition.cnn.com/2012/02/21/world/meast/yemen-elections/index.html.
} 
would not be participating in the elections.

The GCC agreement with Abdullah Saleh also provided for the new mechanism reforming the armed forces, making the new constitution and initiating a national dialogue for political parties ${ }^{16}$. However, after the 2012 elections the marginalized groups i.e. Houthis, Hirak and other tribes perceived the GCC initiative as a power sharing deal for the Yemen's political elite where the marginalized groups were again neglected ${ }^{17}$. Taking the benefit of weaker Govt. these groups including al-Qaeda (AQAP) and IS were able to challenge the writ of the Govt over the southern Yemen ${ }^{18}$. Moreover, during 2012-2-14, the internal rift between Hadi and the Abdullah Saleh's remains also weakened the Government.

In pursuance of the GCC agreement, in early 2014, the National Dialogue Conference outlined a final document of its findings and for making a new constitution which was never implemented. Keeping in view that the proposed draft of the constitutional recommendations proposing for federation consist of six regions was ill received by the Houthis and Hirak ${ }^{19}$. With this the proposal for the extension of the Hadi's term was also became another point of contentious before the beginning of its implementation.

As discussed earlier, during 2012-2014, both the Houthis and their opponents the Saleh loyalists who felt marginalized ${ }^{20}$ were significantly increased their military power by the ongoing transitional period. In the mid of 2014 the Houthis again started a campaign against the Govt to cut the fuel prices ${ }^{21}$. Resulting the continuous protest, the tension rose over by the following months and become more aggressive.

Following the new wave of protests ${ }^{22}$, over the decentralization clause of the new constitution the Houthis forces took control of the Yemeni capital in September 2014. Resulting the conflict, the Houthi's forced the Yemeni government to sign the Peace and National Participation Agreement ${ }^{23}$. The agreement provided for the formulation of the new government, the appointment of the Houthi's and Hirak members as presidential advisors. With this, the agreement also provided for the reformation of security forces and economic settlements. UN and most of the other parties in Yemen also welcomed the peace agreement.

\section{The Outbreak of the Conflict}

The Peace and National Participation Agreement, initially, restored the peace and members of the Houthis were included into the national and security establishment as promised in the agreement. However, again upon the presentation of the new constitutional $\mathrm{draft}^{24}$, the situation in Sana'a deteriorated in 2014. The Houthis took control over the presidential palace with the help of military unites loyal to the former president Sale ${ }^{25}$. Acting president was put into the house arrest and a few days later he stepped down with other government officials including prime minister and cabinet members ${ }^{26}$. After one month, Hadi escaped to Aden and withdrew his resignation and ordered the Houthis to leave San'na. He also announced that the decisions taken under the

\footnotetext{
${ }^{16}$ Crisis Group, Yemen's Military-Security Reform, supra fn 6, p 1. For the English version of the Agreement on the Implementation Mechanism for the Transition Process in Yemen in Accordance with the Initiative of the Gulf Cooperation Council (GCC), see http://peacemaker.un.org/sites/peacemaker.un.org/files/YE_111205_Agreement $\% 20$ on $\% 20$ the $\% 20$ implementation $\% 20$ mechanism $\% 20$ for $\%$ 20the $\% 20$ transition.pdf.

${ }^{17}$ See, note 7.

18 International Crisis Group, Yemen's al-Qaeda: Expanding the Base, 2 February 2017, p i, https://www.crisisgroup.org/middle-east-north-africa/gulf-and-arabian-peninsula/yemen/174-yemen-s-al-qaeda-expanding-base.

19 Y. Bayoumy, 'Yemen's Federal Plan a Bold Idea, but Many Hurdles Remain', Reuters, 23 February 2014, http://www.reuters.com/article/us-yemen-politics-analysis/yemens-federalplan-a-bold-idea-but-many-hurdles-remain-idUSBREA1M057201 40223. See also 'Yemeni Factions Hold National Dialogue', Al Jazeera, 26 January 2014, http://www.aljazeera.com/news/middleeast/2014/01/yemen-wraps-up-thorny-national-dialogue-2014125152420400484.html.

${ }^{20}$ See, note 19

21 'Yemen Fuel Subsidy Cut Drives Poorest Deeper into Poverty', The Guardian, 26 August 2014, https://www.theguardian.com/global-development/2014/aug/26/yemen-fuel-subsidycut-drives-poorest-poverty.

${ }^{22}$ ibid

23 The Peace National Agreement 2014 ,

https://peacemaker.un.org/sites/peacemaker.un.org/files/YE_140921_PeaceNationalPartnershipAgreement_en.pdf

${ }^{24}$ The Houthis do not reject the introduction of a federal system per se, but rather the division of the country's north into three different federal regions, which they seek to control. See M.-C. Heinze, 'The Primacy of Stability over Real Change', Qantara.de, 30 January 2015, https://en.qantara.de/content/the-crisis-in-yemen-the-primacy-of-stability-over-real-change.

25 M. Transfeld, 'Capturing Sanaa: Why the Houthis Were Successful in Yemen', Muftah, 27 September 2014, https://muftah.org/houthis-successful-yemen/\#.WasnpdGx_IW.

26 Security Council Report, 'February 2015 Monthly Forecast', 30 January 2015, http://www.securitycouncilreport.org/monthly-forecast/2015-02/yemen_13.php.
} 
pressure were also invalid and he is still president. In the support of Hadi's government, Gulf states shifted their embassies from Sana'a to Aden ${ }^{27}$.

In March 2015, the situation in Yemen reached to its new phase of violence which led the country into to war. Following the attack on Hadi's house in Aden and deadly suicide attack in Sana'a by the IS $^{28}$. The Houthis launched a large armed movement in the name of fighting Al-Quaeda and IS in the south. Meanwhile the Hadi declared Aden as the temporary capital ${ }^{29}$. On the other hand, the Houthi-Saleh alliance further continued their advances and reached to outskirts of Aden. However, Fearing the Houthi's advances, Hadi left the country and took refuge in Saudi Arabia ${ }^{30}$. Consequently, Hadi asked the Gulf countries for military intervention to protect the country. Shortly after the Yemeni government's request, the Saudi-led alliance announced a military operation to restore the Hadi's rule and to counter the Houthis in Yemen ${ }^{31}$. Despite of the Saudi-led airstrikes the Houthi alliance on ground made significant gains. Besides the Hadi forces there were tribal groups and local militias also flighted against the Houthis.

In April 2015, the UN security council reaffirmed its support to the Yemeni government through a resolution. UNSC also demanded the Houthis to withdraw its control over the occupied areas. Most importantly, it imposed sanctions against the Houthi's head and Saleh's son, as well as established an arms embargo against the forces fighting against the Hadi government ${ }^{32}$. Meanwhile, by the support of Saudi-led ground forces, Hadi managed to retake the control of Aden city.

\subsection{Battel of Hudaydah}

Hudaydah, being the fourth largest city and a port of the Red Sea has gained much importance after the Houthis control. The port is gateway to the goods and aid to the large part of the Yemen. In 2018, the Saudi-led forces launched an operation for liberation of Hudaydah called Operation Golden Victory against the Houthi rebels.

Due to its strategic and geographic importance, many groups were fighting to take the control of the port city ${ }^{33}$. Particularly, for the Houthis who controlled mostly northern areas the port city has significant importance for food and commercial supply. The port is also a maritime checkpoint for the Bab al-Mandab strait. The port also generate revenue for the rebel forces who collects tax from the goods and fuel import through the port.

In the given context, the Operation Golden Victory has been seen as the most concerted opportunity to change the power equilibrium in Yemen. For the Saudi-led coalition, retaking Hudaydah could provide the coalition a leverage in future political settlements with the Houthis. From the coalition point of view, the effort can also turn the war in their favor, especially form the Saudi Arabia's perspective a safe passage for their oil careers and military vessels regaining control of the port is quite crucial.

The Saudi-led coalition has controlled mostly the airport of the city while advancing the outskirts of the city. However, due to Martin Griffiths, the UN Secretary General's Special Envoy for Yemen, the coalition paused its advance to allow him negating for cease-fire. Besides, of the population living in Hudayda, a heavy military advancement could also destroy the port which is the main source of supplying food and fuel inside of Yemen. Despite of limiting a full-scale war, a number of civilians died in a hospital after an airstrike.

Later in 2018, the operation has shifted to the near surrounding of Hudaydah including the historic part of the city which is an UNESCO declared heritage part. To date, south of the Hudaydah is under the control of the

\footnotetext{
27 K. Fahim, 'Houthi Rebels Release Detained Yemeni Ministers', The New York Times,16 March 2015, https://www.nytimes.com/2015/03/17/world/middleeast/houthi-rebels-release-yemeni-officials-from-house-arrest.html.

28 Security Council Report, May 2015 Monthly Forecast, 1 May 2015, http://www.securitycouncilreport.org/monthly-forecast/2015-05/yemen_16.php.

29 'Yemen's President Hadi Declares New "Temporary Capital”, Deutsche Welle, 21 March 2015, http://www.dw.com/en/yemens-president-hadi-declares-new-temporary-capital/

30 A. Al-Haj and M. Michael, 'Yemen's President Flees Aden as Rebels Close in', The Star, 25 March 2015, https://www.thestar.com/news/world/2015/03/25/yemen-president-hadi-fleesaden-palace-as-houthi-rebels-near-officials-say.html; see also K. Abdallah and S. Aboudi, 'Yemeni Leader Hadi Leaves Country as Saudi Arabia Keeps up Air Strikes', Reuters, 26 March 2015, http://www.reuters.com/article/us-yemen-security/yemeni-leader-hadi-leaves-countryas-saudi-arabia-keeps-up-air-strikes-idUSKBN0ML0Y C20150326.

${ }^{31}$ See, note 27

$\begin{array}{rrrrrr}32 & \text { UNSC } & \text { Res } & 2216, & 14 & \text { April }\end{array}$ http://www.securitycouncilreport.org/atf/cf/\%7B65BFCF9B-6D27-4E9C-8CD3-CF6E4FF96FF9\%7D/s_res_2216.pdf.

${ }_{33}$ According to figures from the United Nations Verification and Inspection Mechanism for Yemen (UNVIM), in early to mid-July 2018, 61\% of all cargo discharged was through Hudaydah port. See, United Nations Office for the Coordination of Humanitarian Affairs (UN OCHA), Yemen Humanitarian Update, Covering 10 July - 16 July 2018, Issue 21.
} 
coalition while northern part of the city still under the control of the Houthi rebellions. According to the UNOCHA have helped over 200000 individuals while there are 350000 citizens are still residing in the city ${ }^{34}$. Despite of disruption of water and electricity, the port of Hudaydah is still operating.

\section{YEMEN Who controls what}

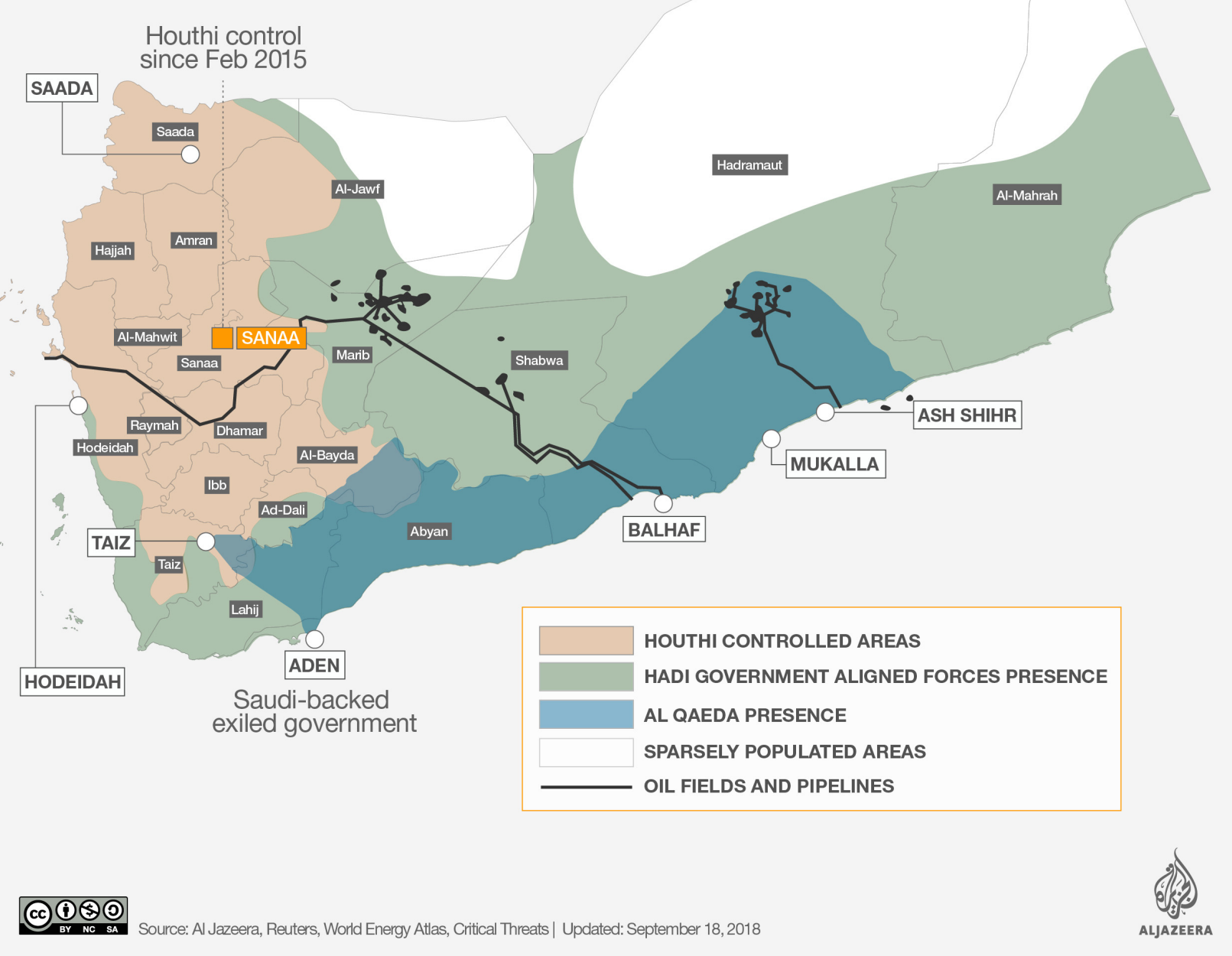

Figure $1^{35}$.

The coalition has advanced with not much resistance northward along the coast towards Hudaydah. Still an attack on the city to push back the Houthis will me more difficult as fighting in the outskirts. The Houthis have taken strong positions along the highways and entry points of the city. They have also dug tranches and laid down landmine along the way. The operation is lead by the UAE along with many regular Yemeni military and irregular groups including; the loyalist of former president Saleh who got killed by the Houthis called the Republican Guards, the southern Yemenis and former soldiers called the Giants Brigade, a local militia called Tihama Resistance Force. These forces have equipped by the UAE with heavy weapons including tanks,

${ }^{34}$ UN OCHA, Yemen Humanitarian Update, Covering August 9-15, 2018, Issue 24.

${ }^{35}$ Source Al-Jazeera, accessed at https://www.aljazeera.com/indepth/interactive/2016/08/yemen-conflict-controls-160814132104300.html 
surveillance and UAVs. ${ }^{36}$

To date, both the coalition and the Houthis are in deadlock and no effort of cease-fire have succeeded. The coalition is insisting for the implementation of the UNSC resolution $2216^{37}$ that calls for complete withdrawal from the Houthis seized areas while the Houthis insists for remain in control. However, the Houthis showed willingness to handover the port under the UN supervision to operate.

\subsection{Attempts for Peace Settlements}

The UN backed efforts were carried out since the beginning of the conflict. However, there were no significant progress have been showed so far. In 2015, the Houthis were showed willingness to accept the UNSC resolution $2216^{38}$ including their departure from the cities they sized and restoration of Hadi's rule with a promise of early elections and registration of the Houthis political party. Following the killing of influential persons and due to the several groups with different goals the deal couldn't succeeded as viewed.

In 2016, the Houthis refused the UN backed plan and appointed a 10-member body to run the country. Consequently, the UN Envoy suspended the peace talks for a month while criticizing the Houthis on announcement of a uniliteral move. Following the announcement of 10 member governing body from the Houthis, the Foreign Ministers of Saudi Arabi, UAE, US and UK met in London and condemned the uniliteral announcement of the Houthis. Resulting the Foreign ministers meeting another settlement was agreed between the parties. Soon after the proposed agreement, the Yemeni government denied any agreements and declared that the Yemeni government has no interest in ceasefire with the Houthis. As stated earlier, due to many groups with different goals it was quite difficult to reach a diplomatic solution.

In 2018, The most recent UN backed development had been seen in Sweden when both the parties were agreed on a ceasefire in Hudayda city that could be starting point of ceasefire in whole country. Both the parties were also agreed on a joint control of Hudaydah port with UN backed supervision and the Houthi rebels. However, after one day of the agreement the ceasefire was broken.

\section{Domestic Actors of Armed Conflict}

\subsection{Saleh-Aligned Forces}

The loyalists of former president Ali Abdullah Saleh consists of three main elements: Political groups, Sunni Tribes and Military. The tribal force mostly consists of his own Sanhan tribe. While the political support comes from the GPS which he was heading. The military element was the most significant element of Saleh's power made him powerful and relevant in political scene of the country. Due to the personal loyalists in the Armed forces and the high ranked officers he appointed during his reign, Saleh enjoyed an important position. The Hadi government reformed the Army to eliminate the Saleh support. However, there were many military unites remained loyal to the former president. In December 2017, Ali Abdullah Saleh was killed by his own allies turned foe the Houthis in an attack just two days after he broke his alliance with the Houthis.

\subsection{The Houthis}

As discussed earlier, the Houthis forms the biggest insurgent group in conflict with the Yemeni government. They enjoy the support of Zaydi sect of Shiite community. During 2004-2010, the Houthis have engaged and launched six attacks against the then president Ali Abdullah Saleh and also most actively lead the protest against Saleh in $2011^{39}$. After Saleh, the leadership vacuum has not been filled. The Houthis took benefit of week government and gathered more support politically and military wise. In later years the former enemies became friend, the Houthi-Saleh alliance took control of the capital in 2014. Despite of closer political alliance the Houthi-Saleh forces were still at distance. The Houthi's military rely on two networks: the militias belong to the area they control, and the former forces men and units joined the Houthi movement in later years. Most of the Houthi forces men and officers are from their own Zayidi community and tribes ${ }^{40}$.

\subsection{Hadi Forces}

As stated above, several militaries unite joined the Houthis and a number of other unites remined loyal to the

\footnotetext{
${ }^{36}$ USAID, Yemen - Complex Emergency Fact Sheet \#9, Fiscal Year (FY) 2018, July 13, 2018.

37 On April 14, 2015, the United Nations Security Council adopted Resolution 2216, which imposed sanctions on individuals undermining the stability of Yemen and authorized an arms embargo against the Houthi-Saleh forces.

${ }^{38}$ Ibid

${ }^{39}$ Briefing paper, Yemen at war, Number CBP7184, 27 April 2017

${ }^{40}$ Ibid
} 
former president Saleh. After taking control, Hadi reformed the Armed forces. In 2016, to gather the tribal support, Hadi appointed Ali Mohsin who was an influenceable tribal leader and a former Saleh loyal as the deputy commander of the Yemeni Armed forces. Mohsin supports the Yemenin forces with his strong network of tribal allies in the country. However, in comparison to the former president, Hadi does not enjoy the full support of allies fighting under the Yemeni Armed forces. Moreover, Hadi also does not enjoy the respect of his allies because of his previous role in 1994 civil war when he fought by the side of northern Army.

\subsection{Al Qaeda in the Arab Peninsula (AQAP)}

In 2009, upon the merger of the Saudi and Yemeni branches of Al-Qaeda a new group found in Yemen. During the 2011 upspring, the group has changed his international role to a local insurgent group with a focus to establish a territorial control in Yemen ${ }^{41}$. The AQAP took benefit of the core attention on the IS and the Houthis from the allied forces and the US strikes. Meanwhile, the AQAP prepared themselves for the future role avoiding conflicts with US and Saudi interest for a time being strategy. The group started to enhance its local influence by practicing local government role in smaller parts in southern territories ${ }^{42}$. The group made significant presence in 2016 and captured five cities in south of Yemen. In early conflict, the group's control over the port of Mukalla provided them a great opportunity to collect revenue. Because of capturing a financial hub, the AQAP wants to become and quasi-state and asked its share in oil export which was denied. However, the group couldn't establish its rule, but it is remained present in Shabwa, Abyen and Hadhramaut areas.

\subsection{Islamic State}

In 2014, the Islamic state branch was launched in Yemen. Contrary to the Al Qaeda, the IS command is consisting of non-Yemeni members. The members of the IS also have experience of war in Iraq and Syria ${ }^{43}$. According to the US state department report, as of 2016 the group consist of 150 members. However, the group does not control any specific area and there is a very less support shown for the IS in Yemen domestically. Due to less aggressive approach of AQAP, many frustrated members of the AQAP have defected to the IS. Although, there are no reports of armed clashes between the two still a strong rivalry exists between the IS and AQAP. Because of its brutal approach the group faces acceptability challenge due to which an internal divide was also observed within the group. The group mostly involved in suicide bombings and small-scale attacks. In 2015, the group claimed responsibility of the deadliest suicide on a mosque in Sana'a.

\subsection{Salafi Militias}

Against the Houthis, there are a number of small alliances made by the Saudi-led forces. UAE controls the Salafi groups as an irregular army in Aden. However, these groups are nominally aligned with the Yemeni armed forces and takes part separately on ground ${ }^{44}$.

\section{International Involvement in Yemen and Proxies}

\subsection{Role of the United Nations in Yemen}

Since the uprising broke out in 2011, the UN has been actively involved in restoring peace through Secretary-General offices to find out a peaceful settlement in the region. As the conflict deepened, the UN Security Council adopted an important resolution 2014 in 2011. Through which, the UN provided backing for the negotiation between the Yemeni government and opposition which resulted in agreement of Gulf Cooperation Council (GCC) initiative. The UNSC resolution 2014 mostly focused on the security aspect of the region and there was less focus on the economic and social condition of the Yemen. In 2014, the UNSC also adopted another very crucial resolution 2216 that recognizes the Saudi-led intervention in support of the Hadi rule and called for the withdrawal of the areas that seized by the Houthis. The resolution also imposed an arms embargo against Yemen. Keeping in view of the Houthis control over the majority area of the Yemen, the resolution 2216 looks irrelevant as the Houthis already claimed them as the winning party in Yemen. Therefore, despites of several UN backed deals and agreements between the conflicting parties so far, no settlement had paid of the purpose of a peaceful solution.

\footnotetext{
41 International Crisis Group, Yemen's al-Qaeda: Expanding the Base, 2 February 2017, p i, https://www.crisisgroup.org/middle-east-north-africa/gulf-and-arabian-peninsula/yemen/174-yemen-s-al-qaeda-expanding-base.

42 See note 35

${ }^{43}$ Ibid

44 S. A. Seche, 'Shaping the South: The UAE in Yemen', The Arab Gulf States Institute in Washington, 4 May 2017, http://www.agsiw.org/shaping-south-uae-yemen.
} 


\subsection{Role of the United States in Yemen}

The United States was engaged against AQAP through airstrikes and drone operations dates back to Saleh's rein. Historically, the US has deep rooted interests and strategic allies in the region. Following the Iran's support for the Houthis, the role of the US become more pivotal as a key state involved in the conflict to protect its regional interest. Particularly, in the backdrop of situation in Syria and Russia-Iran alliance, the US role in protection of its allies in middle east became more crucial. Moreover, the threats posed the Houthis in Red Sea for the commercial and military ships made situation more fragile. Therefore, the Commander of United States Central Command General Votel on August, 2018 stated that:

"the Bab-el-Mandeb is open for business, as far as we're concerned. And I would say it's a major -- it's a major waterway, not just for the United States, but for many countries in terms of moving through that particular area. So, one of our key missions here is to ensure freedom of navigation, freedom of commerce, and we will continue to exercise that through the region. ${ }^{45}$

Consequently, after the Saudi-led ground operation, the Hadi government revoked its permission of to the US for ground operations. However, the US is actively involved in Saudi-led coalition throughout the conflict. The US is supporting the Saudi Arabia by supplying arms to the Saudi-led alliance, intelligence sharing, refueling fighter Jets and through providing logistic support to the Saudi Arabia.

\subsection{The role of United Kingdom and France}

Since the ground operation launched by the Saudi-led coalition, the United Kingdom and France both supplied heavy weapon to the coalition in support of Hadi government. For the training of Saudi pilots, France provided the training and increased its arms sell to Saudi Arabia. For the collaboration and support in the joint headquarters, officers from France and UK are present during air operations.

Besides the UK arms supply, a question whether the UK personnel are also engaged in the conflict. In this regard, the UK defence ministry's spokesman stated that:

"UK military personnel are not directly involved in Saudi-led Coalition operations, we are offering Saudi Arabia advice and training on best practice targeting techniques to help ensure continued compliance with International Humanitarian Law. We support Saudi forces through longstanding, pre-existing arrangements and will consider any new requests." 46

In 2016, the UK Foreign Secretary provided details as:

"I cannot tell him whether it is six people, but we do have a military presence in Saudi Arabia, and we are working with the Saudi Arabians to ensure the following of correct procedures to avoid breaches of international humanitarian law-to ensure that target sets are correctly identified and processes correctly followed and that only legitimate military targets are struck. It is important that we ensure Saudi Arabia has that capability."

He further states that:

"We also use the personnel who are present as a quick check —it can only be a quick first check-when we receive reports, as we have recently, of breaches of international humanitarian law that would, for example, involve the deliberate striking of civilian targets. So far, in every case, our people on the ground have reported that there is no evidence of deliberate breaches of international humanitarian law." ${ }^{47}$

About the foreign military personnel's involvement, the Saudi Foreign Minister admitted that there are foreign military personnel including personnel from UK are engaged in the control center and they also aware of the targets.

\subsection{Saudi Arabia}

In the context of historical ties with Yemen, Saudi Arabia have strong strategic and political interests in Yemen ${ }^{48}$.

${ }^{45}$ Yemen War and Regional Intervention, Congress report

46 Defence in the Media blog, MoD News Team, 8 January 2016

${ }^{47}$ HC Deb 12 Jan 2016, c697

${ }^{48}$ During the Cold War, Saudi Arabia's leaders supported northern Yemeni Zaydis as a bulwark against nationalist and leftist rivals, and engaged in proxy war against Egypt-backed Yemeni nationalists during the 1960s. The revolutionary, anti-Saudi ideology of the Houthi movement, which emerged in the 1990s, presented new challenges. In 2009, Saudi Arabia launched a three month air and ground campaign in support of the Yemeni government's Operation Scorched Earth. Saudi Arabia dispatched troops along the border of its southernmost province of Jizan and Sa'dah in an attempt to repel reported Houthi infiltration of Saudi territory. It is estimated that Saudi Arabia lost 133 soldiers in its war 
Particularly, the Houthi acting as a proxy of Iran, poses serious threat to the security of Saudi Arabia that shares a long border with Yemen. As states earlier, the Red Sea route is very important for Saudi oil vessels and presence of the Houthi rebellions along the route is continues threat for the Saudi commercial interests. Following the aggressive Saudi airstrikes, in July 2018, the Houthis attacked two oil tankers belong to Saudi Arabia in Red $\mathrm{Sea}^{49}$. Therefore, Saudi Aramco halted its oil shipments passing through Bab Al Mandab strait. ${ }^{50}$

Since its, against the Houthis insurgency, Saudi Arabia has taken a strong position in support of Yemeni government. In 2010, the Houthi militants entered in Saudi land and killed two Saudi border security guards. It provoked Saudi reaction which resulted into retaliation and airstrikes. During 2009-2010 there were a number conflict happened among the Saudi border forces and the Houthis resulting thousands of Yemeni displaced persons. After the conflict, Saudi Arabia put a big number of soldiers along the southern border near the Houthi's controlled areas. Moreover, Saudi Arabia also suspended its aid to the Yemen after the Houthis control.

Because of the long-shared border with Yemen, Saudi Arabia's security concerns are seeming quite genuine. Fearing the cross border increasing conflicts and movement, Saudi Arabia started building a border fence along the Saudi-Yemen border as well as Saudi-Iraq border. With this, Riyadh also concerned about its own Shia population mostly reside in the Eastern province which has been faced turmoil in form of protests in the near past.

\subsection{Iran's Involvement in Yemen}

Saudi Arabia's claims of Iran's involvement are mostly considered as exaggeration to put pressure on its foes. While there are strong historical and now strategic ties between the Houthis and Iran have been seen in the context of Yemen conflict particularly. However, the support received from Iran is largely based on training and arms shipments ${ }^{51}$. On policy making the Houthis group still rely on its allies and on domestic factors which cannot be heavily influenced by Iran. As discussed earlier, the Houthi movement is originated from the Zaidi sect of Shiite Islam. The Houthis have also shown a strong support for the Iranian political stance in the region. The Houthi leaders also expressed their likeness for the Irani supreme leader and also for the Hizballah militia which is backed by Iran. Due to the Houthis inclined towards Iran, the Gulf states including their foreign allies i.e. the US claims that the Houthis have been supported and Iran to enhance its influence in the region. Despite of Iranian arms supply and logistic support, there are not much evidence reported in this regard. However, the Houthis close ties with Iran is not a secret, in an interview a Houthi leader openly admitted that they expect support from Iran as:

"Ansar Allah expects the Islamic Republic of Iran and other countries to support them and the Yemeni people...The revolution in Yemen...is inspired by the Islamic Revolution in Iran...but the intellectual and historical roots of revolution in Yemen stem from the fact that Yemenis are Zaidis and have more political experience than the Islamic Republic. From Ali's son, Imam Zaid up to now, Zaidis have witnessed many revolutions against unjust rulers." ${ }^{52}$

However, the Zaidi sect of Shiite Islam claims that there are significant jurisprudential and beliefs differences between Zaidis and the Twelver Shittes. They also assert that the Zaidi sect is theologically closer to the Sunni Islam as they have in Yemen.

On the other hand, after the control on Sana'a, the relations of the Houthis with Iran appeared more strengthened than ever. Following the victory, a Houthi delegation visited Iran and received an economic package in form of one-year oil supply from Iran. In 2015, they signed an aviation agreement with the Iranian aviation, initiated four daily flights between Tehran and Sana'a for establishing a closer connection ${ }^{53}$.

The Houthis militia do not entirely dependent on Iran. Most of their manpower comes form their own tribe and allies in Yemen. However, Hizballah and Iran have supported the Houthis insurgents with training, arms, logistic support and through advice. Therefore, an unnamed Hizballah official stated in an interview in 2016 about their

\footnotetext{
49 "Yemeni Houthis fire at ship with Iranian-supplied missile," Threat Matrix, Foundation for the Defense of Democracies, October 5th, 2016. See also, "This Could Be Why Rebel Missiles Keep Missing U.S. Warships," Esquire, October 13, 2016.

50 "Saudi Arabia halts Oil Exports in Red Sea Lane after Houthi Attacks," Reuters, July 25, 2018.

${ }^{51}$ According to the U.S. intelligence community, "Iran's support to the Houthis further escalates the conflict and poses a serious threat to US partners and interests in the region. Iran continues to provide support that enables Houthi attacks against shipping near the Bab al Mandeb Strait and land-based targets deep inside Saudi Arabia and the UAE." See, Office of the Director for National Intelligence, Testimony Prepared for Hearings on Worldwide Threats, February 2018.

52 Mehdi Khalaji, 'Yemen's Zaidis: A Window for Iranian Influence' Washington Institute for Near East Policy, 2 February 2015

${ }^{53}$ Suzanne Dahlgren, 'Four Weddings and a Funeral in Yemen', Middle East Research and Information Project, 20 March 2015
} 
support to the Houthis as:

"After we are done with Syria, we will start with Yemen, Hezbollah is already there.... Who do you think fires Tochka missiles into Saudi Arabia? It's not the Houthis in their sandals" ${ }^{54}$ it's us.

Resulting the undeclared but open support from Iran, the Saudi Arabia's concern over Iran's involvement in Yemen looks justified. From Iran's perspective, supporting the Houthis in low-cost way to enhance its influence in Yemen and to counter its rival Saudi Arabia without engaging itself in a direct armed conflict with Iran. However, Iran's support for the Houthis does not reach to the level they provided for the proxies in Syria and Iraq. It's may be because of its deep in engagement in Syria and Iraq, Iran is not a position to support the Houthis in Yemen at full scale.

The Iranian missile aid is somewhat a worrisome aspect for the Saudi-led coalition. In 2017, the Houthis fired Burkan-2H missile which is an Iran manufactured weapon. In this context, General Votel, Commander of the United States Central Command stated that:

"Certainly, as we've seen with Ambassador Haley and her demonstration, most recently, with some of the items recovered from Saudi Arabia, these weapons pose the threat of widening the conflict out of ... Yemen and, frankly, put our forces, our embassy in Riyadh, our forces in the United Arab Emirates at risk, as well as our partners'.... As we look at places like the Bab-el-Mandeb, where we see the introduction of coastal defense cruise missiles, some that have been modified, we know these are not capabilities that the Houthis had. So they have been provided to them by someone. That someone is Iran." 55

Later in 2018, the UN expert panel on Yemen produced a report in the UNSC in which the panel suggested that it is quite possible that Iran is violating the international arms embargo by supplying the Houthis more advanced missiles. Moreover, after inspecting the debris of missiles fired from the Houthis in Saudi territory, the UN experts noted that these missiles show the characteristics of Iranian missile system and also there was great possibility that these weapons were manufactured outside of Yemen ${ }^{56}$. With this, the US department of foreign asset control (OFAC) identified Iranian individuals who were acting on behalf of Revolutionary Guards, have transferred missile related expertise to the Houthis which was never observed before in the Yemen conflict.

\subsection{Role of UAE in Yemen}

As an important part of the Saudi-led coalition, the United Arab Emirates playing a significant role in the region as a key player. The UAE largely confined its role in the western and southern coats of Yemen. The UAE forces are fighting to retake the occupied area by the Houthis and other rebellions including AQAP. With this, the United Arab Emirates also supporting the Salfi groups in the region to fight against the Houthis as its allies ${ }^{57}$. The UAE also maintained distance from the other Sunni groups and Yemeni forces. To date, the UAE has lost more than 100 soldiers in Yemen.

In Aden city, the Hadi forces and the groups supported by the UAE were indulged in clashes against each other. The role of UAE in Aden city is quite of significant as it controls the Aden city by its ground forces and allied militias. The UAE controls the Aden city port, airport and has also rebuild the infrastructure of the city. The Hadi forces controls a limited part of the city as compared to the UAE backed groups.

Besides fighting the Houthis and engaging in internal conflict with the Hadi's allies, the UAE is a key player in fighting against the AQAP. Through direct intervention and by building up proxies the UAE has put its efforts to liberate the territories occupied by the AQAP. While fighting against the AQAP at the Mukallah port, the US and the UAE forces have also fought jointly in 2016. The United Arab Emirates also claimed that they have trained a large number of militants for fighting against AQAP. However, there are reports that the UAE also financing militants of the extremist groups for joining the UAE backed militias.

\section{Members of the Saudi Arabia-Led Coalition}

All the members of the GCC except Oman, have joined the coalition led by the Saudi Arabia. The Oman desires a role of mediator. In this coalition, the Saudi Arabia has contributed the major part of the armed forces. Besides the Saudi Arabia and the UAE who are playing most active role in Yemen, the other countries including Jordan, Sudan, Morocco and Egypt are also part of the Saudi-led coalition. Particularly, The Egypt has played a key role

\footnotetext{
54 “The Houthi Hezbollah: Iran's Train-and-Equip Program in Sanaa,” Foreign Affairs, March 31, 2016.

55 House Armed Services Committee Hearing on Terrorism and Iran, Full Transcript, February 27, 2018.

56 "UN panel finds further Evidence of Iran Link to Yemen Missiles,"Agence France Presse, July 30, 2018.

${ }^{57}$ https://www.washingtoninstitute.org/policy-analysis/view/the-uae-and-yemens-islah-a-coalition-coalesces
} 
in the Sea through actively participating in patrolling in the Red sea and also engaged in bombing the Houthi posts by its navy.

In 2015, Malaysia and Senegal also joined the Saudi coalition. Senegal promised to send more than two thousand soldiers. Pakistan has also joined the coalition in 2018 but the support form Pakistan is more focused on training part of the forces.

\section{The US Support for the Coalition}

From the outset of the Iran's involvement in Yemen, the Saudi-led coalition sought help from its old ally the United States. In 2015, the US government authorized the intelligence and logistic support for the Saudi-led coalition. A joint planning cell was established for intelligence sharing and logistic support. With this, the US also provided support in training the troops and mid-air fueling the fighter jets combating against the insurgents ${ }^{58}$.

\section{Prospects for the Coalition}

The coalition Saudi Arabia has anticipated to fight against the Houthis, is not that strong as Saudi Arabia has wanted in this war. Besides supporting initially, Sunni countries having strong militaries such as Turkey and Pakistan also dis not sent their forces and limited their support mostly on diplomatic front. Although the Egypt has supported the coalition with their navy to secure Bab al-Mandab which has a strategic importance in Red Sea has not sent a significant number of ground forces to fight in Yemen. In this regard, the role of Muslim Brotherhood has become critical as the Yemen branch of the group is matter of disagreement between the UAE and the Saudi Arabi. Keeping in view that the UAE has banned Muslim Brotherhood and declared them a terrorist organization. Therefore, the UAE is supporting Salafi groups as their proxy in Yemen.

Although, Saudi Arabia has declared that the Houthis are nothing more than a proxy of Iran. However, it is observed that the Houthis acts independently with their local allies and on some occasions act contrary to the Iranian policy. Despite of independent decision making, the Houthis also gets military and moral support from Iran.

An Irani official termed Saudi's intervention in Yemen as an opportunity for Iran to benefit the situation in Yemen as:

"The reality is that Iran's influence in Yemen is minimal, and the Saudis know this. Yemen is far from our shores. We didn't need to send arms to Yemen before the war, and now it is practically impossible to do so. But from a strategic perspective, the conflict in Yemen has no cost for us and even has some benefits." ${ }^{59}$

On the other hand, after the execution of Nimr al-Nimr, an influential Shitte cleric residing in Saudi Arabia, Iran threatened to send military advisors in Yemen to provide assistance to the Houthis with Russian cooperation.

\section{Goals of the Saudi-Led Coalition}

The principle goal of Saudi Arabia's intervention in Yemen is to restore the legitimate Yemeni government seized by the rebellions. However, Saudi Arabia also have broader regional objectives. Through this intervention, Saudi Arabia also intends to secure its interest by preventing the Iranian influence in Yemen and to strengthen in position in GCC as a leader ${ }^{60}$.

In this regard, the former US ambassador to Yemen, Barbra Bodine describes the Saudi's interests as:

"The Saudis did not have a clear idea of an endgame beyond putting the Hadi government back in charge. Securing the border between Yemen and Saudi Arabia was a strategic objective, but [most of] the fighting has been in the south. What their endgame is, beyond a Yemen that doesn't threaten its borders and isn't controlled by Iran, is pretty unclear. There has not been any real reconstruction - political reconstruction, physical infrastructure - and there is no "day after" plan."

Barbra Bodine further states that:

"The Saudis went in with the hubris that given the size and sophistication of their air force and the prowess of Emirati ground troops, this would be a short war; the Houthis, a ragtag insurgency, would

\footnotetext{
${ }^{58}$ Refueling operations began April 7, 2015 according to Department of Defense spokesman Col. Steve Warren. See Andrew Tilghman,

"U.S. launches aerial refueling mission in Yemen,” Military Times, April 8, 2015.

${ }^{59}$ International Crisis Group: Yemen: is Peace Possible?, p11-12, 9 February 2016

${ }^{60}$ Bilal Y. Saab, 'Houthi and the Blowback', Foreign Affairs, 29 March 2015
} 
collapse after "shock and awe." It has not worked out that way." ${ }^{\text {"1 }}$

Barbra Bodnie's anticipation of Saudi Arabi's interest depicts a partial reality. The ground situation and the Saudi's advancement in the region has shown a continue increase which has far reaching impact on the region.

In order to destroy the alliance of Saleh loyal military units and the Houthis, Saudi Arabia's airstrikes aimed to target the regular army of Saleh loyalists. Saudi Arabia also aimed to sabotage the fragile alliance between the Houthis and Saleh. However, later, there were significant collaboration have seen between them until Saleh's killing.

\section{Conclusion}

The Yemen crises is complex in nature. The country has been divided and in control of many groups fighting for different goals. The major parties in conflict are the Houthis rebellions and the President Hadi forces with the support of Saudi Arabi, UAE and other coalition forces. The coalition also receives the support from the US, UK and France while the Houthis are getting support by Iran and some other opposition groups.

The Saudi-led coalition has achieved partial success by conducting a regressive airstrike campaign against the Houthis. To date, the Houthis are controlling much of the country including Sana'a and Hudaydah the most significant post city of the country. While the Hadi government controls Aden city and rest of the area with their tribal allies. However, the coalition have not succeeded in retaking the control of Sana'a and the Hudaydah city so far. The presence of the Houthis threatens the Saudi borders and Bab- al Mandab which is an important water way for the Saudi oil careers and military vessels.

For the US the situation in Yemen is also complex equation where limiting the support would lead to the increase in Iranian influence and can be interpreted as abandoning its old allies in the region. While supporting them could increase the humanitarian cost of the conflict. Keeping in view of the recent policy change by the American President Donald Trump, the crises in Yemen could potentially turn into worse condition if the conflict priest longer in case of leaving the power vacuum for long time.

\section{Copyrights}

Copyright for this article is retained by the author(s), with first publication rights granted to the journal.

This is an open-access article distributed under the terms and conditions of the Creative Commons Attribution license (http://creativecommons.org/licenses/by/4.0/).

${ }^{61}$ Council on Foreign Relations, The Futility of Force in Yemen, 13 March 2017 